\title{
PEMANFAATAN URIN SAPI MENJADI PUPUK ORGANIK CAIR KELOMPOK TANI DESA SUKADAMAI TIMUR
}

\author{
Jasmidi $^{1 *}$, Zainuddin $\mathbf{M}^{1}$, Puji Prastowo ${ }^{2}$ \\ ${ }^{1}$ Jurusan Kimia, Fakultas Matematika dan Ilmu Pengetahuan Alam, Universitas Negeri Medan \\ ${ }^{2}$ Jurusan Biologi, Fakultas Matematika dan Ilmu Pengetahuan Alam, Universitas Negeri Medan \\ Jl. Willem Iskandar pasar V-Kotak Pos No. 1589 - Medan 20221 \\ *Penulis Korespodensi : Jasmidi@unimed.ac.id
}

\begin{abstract}
Abstrak
Telah dilakukan kegiatan pengabdian berupa pemanfaatan urin sapi menjadi pupuk organik cair pada kelompok tani "Sidodadi" dan "Maju II" desa Sukadamai Timur. Tujuan kegiatan ini adalah 1) meningkatkan pengetahuan dan keterampilan petani/peternak dalam membuat pupuk organik cair dari urin sapi sebagai bahan utama 2) membantu meningkatkan pendapatan dan kesejahteraan petani/peternak dari sub-sektor pertanian. Kegiatan pengabdian ini dimulai dengan metode pendekatan dengan menjalin kerjasama tim pelaksana dengan LPM Unimed dan pemerintah setempat serta kedua Kelompok Tani, dilanjutkan dengan penyuluhan dan pelatihan serta penerapan langsung oleh petani/peternak. Hasil-hasil yang diperoleh adalah anggota kader dari masing-masing kelompok mitra telah : (1) memiliki pengetahuan dan wawasan tentang potensi dan pemanfaatan urin sapi menjadi pupuk organik cair, (2) memiliki keterampilan dalam pembuatan pupuk organik cair, (3) pupuk yang dihasilkan berpengaruh positif terhadap tanaman.
\end{abstract}

Kata kunci : urin sapi, pupuk organik cair

\begin{abstract}
The service activities have been carried out at the "Sidodadi" and "Maju II" farmer groups, East Sukadamai village by the utilization of cow urine as the starter in liquid organic fertilizer. The main purpose of this activity is 1) to improve the knowledge and skills of farmer/ranchers in making liquid organic fertilizer from cow urine as a main ingredient 2) to help improving the income and welfare of farmers/ranchers from the agricultural sub-sector. This service activities began with a partnership approach with the implementation team with LPM Unimed and local governments as well as the Farmers Group, followed by counseling and training as well as direct application by farmers. The results of implementation of the project showed that the member of each groups; (1) have the knowledge and insight about the potential and the usage of cow urine as starter in fabrication of liquid organic fertilizer; (2) have good skill to prepare liquid organic fertilizer; (3) have shown the positive effect of the liquid organic fertilizer on growing the plant.
\end{abstract}

Keywords : cow urine, liquid organic fertilizer

\section{PENDAhuluan}

Pupuk merupakan kebutuhan utama bagi para petani dan perkebunan untuk memperoleh hasil tanaman yang optimal, oleh karena itu kelangkaan dan mahalnya harga pupuk menjadi masalah bagi petani, dan juga bagi perkebunan-perkebunan.

Persedian pupuk subsidi di tingkat pengecer saat ini sangat terbatas padahal kebutuhan akan pupuk semakin meningkat, sementara itu harga pupuk non subsidi dibanding pupuk subsidi sangat berbeda contoh pupuk urea bersubsidi Rp 2.500/kg, sedangkan pupuk urea non subsidi mencapai Rp 5.000,- bahkan beberapa jenis pupuk NPK seperti merk Mutiara harganya saat ini sangat tinggi yaitu di atas Rp. $10.000 / \mathrm{kg}$.
Selain harga yang mahal, penggunaan pupuk kimia (anorganik) oleh para petani secara berlebihan dan terus-menerus menyebabkan kerusakan lahan, hilangnya unsur hara, tanah menjadi asam akibatnya banyak unsur hara yang terikat dan tidak dapat dimobilisir ke tanaman sehingga menyebabkan produktivitas tanaman menjadi rendah (Widjayanto and Miyauchi, 2003, Amilla, 2011). Hal ini tentunya juga akan berdampak pada tingkat pendapatan petani dari usaha pertanian menurun (Sudiarto, 2008).

Kebutuhan akan pupuk yang sedemikian tinggi dan harga yang mahal menjadi masalah dan sekaligus menjadi peluang untuk memanfaatkan bahan-bahan yang kurang berguna seperti limbah peternakan maupun pertanian menjadi pupuk organik baik 
organik padat maupun cair dengan cara membuat sendiri. Seperti dengan memanfaatkan kotoran sapi, kambing, domba, ayam, jerami padi, pelepah sawit maupun bahan-bahan lainnya..

Menurut Simamora dan Salundik (2008), penggunaan pupuk organik kesuburan dan kegemburan tanah akan terjaga. Penggunaan pupuk organik seperti kompos dapat memperbaiki produktivitas tanah, baik secara fisik, kimia, maupun biologi tanah. Secara fisik, kompos bisa menggemburkan tanah, memperbaiki aerasi dan drainase, meningkatkan pengikatan antarpartikel dan kapasitas mengikat air sehingga dapat mencegah erosi dan longsor, mengurangi tercucinya nitrogen terlarut serta memperbaiki daya olah tanah. Secara kimia, kompos dapat meningkatkan kapasitas tukar kation (KTK), ketersediaan unsur hara, dan ketersediaan asam humat. Asam humat akan membantu meningkatkan proses pelapukan bahan mineral. Secara biologi, kompos yang tidak lain bahan organik ini merupakan sumber makanan bagi miroorganisme tanah. Dengan adanya kompos, fungi, bakteri serta mikroorganime menguntungkan lainnya akan berkembang lebih cepat. Banyaknya mikroorganisme tanah yang menguntungkan akan menambah kesuburan tanah.

Selain itu Pupuk kompos memiliki keunggulankeunggulan yaitu : 1) memperbaiki struktur tanah lahan pertanian atau media tanam, 2) memiliki kandungan unsur mikro dan makro yang lengkap meskipun sedikit, 3) ramah lingkungan karena akan menjaga kelestarian lingkungan 4) murah dan mudah didapat, bahkan dapat di buat sendiri, 5) mampu menyerap dan menampung air lebih lama dibandingkan dengan pupuk kimia 6) membantu meningkatkan jumlah mikroorganisme pada media tanam, sehingga dapat menghasilkan unsur hara tanaman . Demikian pula Pupuk organik lebih baik dari pada pupuk kimia karena pupuk kimia dapat mencemari dan merusak lingkungan (tanah) jika digunakan berlebihan. Dibandingkan kompos, pupuk kimia sangat sulit diserap oleh tanaman, sulit diuraikan air, dan dapat meracuni produk yang dihasilkan oleh tanaman. Hasil penelitian menunjukkan pupuk kimia mengandung radikal bebas dan berbahaya bagi manusia karena dapat mengendap didalam buah yang dihasilkan. Sebagian pupuk kimia yang tidak diserap oleh tanaman juga akan menumpuk ditanah dan tidak dapat diuraikan oleh air. Kondisi seperti ini menjadikan tanah tidak produtif. Akibatnya mikroorganisme yang bertugas menggemburkan tanah tidak akan beraktivitas ditanah tersebut (Saputra, 2007)

Kotoran hewan memungkinkan dijadikan sebagai bahan baku pupuk organik karena kandungan unsur haranya cukup baik. Adapun kandungan zat hara pada beberapa kotoran ternak padat dan cair terlihat pada tabel 1 berikut :

Tabel 1. Jenis dan kandungan zat hara pada beberapa kotoran ternak padat dan cair

\begin{tabular}{lcccc}
\hline $\begin{array}{l}\text { Nama ternak dan bentuk } \\
\text { kotorannya }\end{array}$ & $\begin{array}{c}\text { Nitrogen } \\
(\%)\end{array}$ & $\begin{array}{c}\text { Fosfor } \\
(\%)\end{array}$ & $\begin{array}{c}\text { Kalium } \\
(\%)\end{array}$ & $\begin{array}{c}\text { Air } \\
(\%)\end{array}$ \\
\hline Kuda -padat & 0,55 & 0,30 & 0,40 & 75 \\
Kuda -cair & 1,40 & 0,02 & 1,60 & 90 \\
Kerbau -padat & 0,60 & 0,30 & 0,34 & 85 \\
Kerbau -cair & 0,50 & 0,15 & 1,50 & 92 \\
Sapi -padat & 0,40 & 0,20 & 0,10 & 85 \\
Sapi -cair & 1,00 & 0,50 & 1,50 & 92 \\
Kambing -padat & 0,60 & 0,30 & 0,17 & 80 \\
Kambing -cair & 1,50 & 0,13 & 1,80 & 60 \\
Domba -padat & 0,75 & 0,50 & 0,45 & 85 \\
Domba -cair & 1,35 & 0,05 & 2,10 & 80 \\
Babi - padat & 0,95 & 0,35 & 0,40 & 87 \\
Babi -cair & 0,40 & 0,10 & 0,45 & 55 \\
Ayam -padat dan cair & 1,00 & 0,80 & 0,40 & \\
\hline
\end{tabular}

Sumber : Lingga, 1991

Berdasarkan tabel 1 terlihat bahwa kotoran hewan padat maupun cair atau urinnya mengandung zat hara berupa unsur nitrogen, fosfor dan kalium, pada tabel tersebut terlihat pula kandungan zat hara pada urin sapi, terutama jumlah kandungan nitrogen, fosfor, kalium, lebih banyak jika dibandingkan dengan kotoran sapi padat.

Berdasarkan kandungan NPK kotoran hewan, maka kotoran hewan padat maupun cair atau urinnya dapat dijadikan sebagai pupuk organik padat maupun pupuk organik cair. Pupuk organik cair merupakan salah satu pupuk yang berbentuk cair yang berisikan unsur hara organik. Hal yang perlu dipersyaratkan dalam pupuk organik adalah kandungan unsur N,P, K dan unsurunsur hara lain yang berperan dalam penyediaan hara tanaman, selain unsur hara, maka pupuk organik cair berisikan mikroba yang mempunyai sifat fiksasi nitrogen dan pelarut phosfat. 
Desa Sukadamai Timur Kecamatan Hinai kabupaten Langkat merupakan desa pemekaran dari desa Sukadamai yang terletak sekitar $65 \mathrm{~km}$ ke arah Barat laut dari kota Medan, mata pencarian sebagian besar penduduk desa Sukadamai Timur adalah bertani dan berkebun, seperti menanam padi sawah, palawija dan sayur-sayuran sedangkan berkebun yang mereka kembangkan adalah kebun sawit dan karet selain juga beternak sapi. Berdasarkan hasil wawancara dan survey kebutuhan pupuk untuk pertanian dan perkebunan para anggota kelompok tani Sidodadi dan Maju II masih tergantung pada pupuk kimia yang harganya relatif mahal dan terkadang sulit didapat, padahal mereka memiliki bahan baku yang berlimpah, hanya sebagian kecil saja dari mereka yang memanfaatkan limbah padat peternakan menjadi pupuk organik padat, sedangkan urin dari sapi maupun kambing terbuang percuma, tanpa dimanfaatkan sama sekali. Pemanfaatan pupuk kandang atau pupuk organik padat menyulitkan dalam aplikasinya dilapangan, karena jumlah yang diberikan harus banyak sehingga membutuhkan banyak tenaga. Salah satu upaya yang dilakukan untuk mengatasi masalah bulky adalah dengan mengolahnya menjadi pupuk organik cair. Dengan penerapan teknologi, urin sapi kotoran padatnya yang merupakan limbah dapat diproses menjadi pupuk organik cair yang mengandung hara tinggi serta lebih mudah dan murah diaplikasikan dilapangan (http://pustaka.litbang.pertanian.go.id/publikasi/wr30 6083.pdf). Namun saat ini para anggota kelompok tani belum memiliki pengetahuan dan ketrampilan dalam membuat dan penggunaan pupuk organik cair. Pemanfaatan limbah peternakan berupa urin sapi untuk dijadikan pupuk organik cair diharapkan dapat menjawab permasalahan yang dihadapi oleh kedua kelompok tani dalam mengembangkan usaha pertaniannya, sehingga akan menurunkan biaya pemupukan akibatnya akan meningkatkan hasil pertanian dan perkebunan yang tentunya juga akan berimbas pada peningkatkan pendapatan dan kesejahteraan para petani/peternak.

Berdasarkan hasil wawancara tim pelaksana dengan kedua kelompok tani "Sidodadi" dan "Maju II", permasalahan pokok yang dihadapi petani yaitu ketergantungan akan pupuk kimia. Untuk itu perlu memberikan pengetahuan dan ketrampilan untuk membuat pupuk organik cair dari limbah peternakan berupa urin sapi. Sehingga tujuan yang hendak dicapai dari kegiatan pengabdian ini adalah meningkatkan pengetahuan dan ketrampilan petani/peternak untuk membuat pupuk organik cair dari urin sapi serta membantu meningkatkan pendapatan dan kesejahteraan petani/peternak.

\section{BAHAN DAN METODE PELAKSANAAN}

Bahan yang diperlukan untuk membuat pupuk organik cair adalah: urine sapi $\pm 70 \mathrm{~L}$ dan feses sapi $\pm 20 \mathrm{~kg}$, molase $750 \mathrm{~mL}$, nutrisi tambahan (dedak $2 \mathrm{~kg}$ ), empon-empon (temu lawak,temu ireng dan kunyit) 5 $\mathrm{kg}, \quad 250 \mathrm{~mL}$ EM4, tanaman hijauan $\pm 2 \mathrm{~kg}$, buahbuahan busuk, pohon pisang $\pm 3 \mathrm{~kg}$ dan abu dapur.

Untuk mengubah limbah peternakan terutama urin sapi yang selama belum termanfaatkan menjadi bahan yang memberikan kontribusi keuntungan, maka limbah peternakan diubah menjadi pupuk organik cair sebagai kegiatan baru yang menguntungkan. Untuk pencapain tersebut maka metode pendekatan yang ditawarkan untuk menyelesaikan permasalahan prioritas kedua mitra adalah:

a. Menjalin Kerjasama Tim Pelaksana dan LPM UNIMED dengan Pemerintahan daerah Setempat yaitu Kepala Desa Sukadamai Timur dan Kelompok Tani "Sidodadi" dan "Maju II" untuk kemudahan proses dilapangan.

b. Sosialisasi dan Penyuluhan Kedua Mitra "Sidodadi" dan "Maju II" tentang kegiatan IbM dilanjutkan cara mengolah limbah perternakan sapi berupa urine dan feses menjadi pupuk organik cair melalui proses fermentasi dengan menggunakan fermenter EM4. Penyuluhan ini diberikan kepada masing-masing 6 orang kader dari kelompok tani "Sidodadi" dan "Maju II" untuk efisiensi dan intensitas pelaksanaan program.

c. Pelatihan 6 orang kader dari masing-masing mitra dalam proses pembuatan pupuk organik cair dari limbah ternak sapi dengan metode fermentasi.

d. Melakukan pendampingan kepada masing-masing mitra dalam pembuatan pupuk organik cair dari limbah ternak sapi dengan metode fermentasi secara mandiri

e. Memberikan motivasi pada kader kelompok tani "Sidodadi" dan "Maju II" untuk memproduksi pupuk organik cair dengan memanfaatkan limbah ternak sapi sebagai bahan baku dengan metode fermentasi, serta pengalikasiannya pada lahan dan tanaman mereka masing-masing.

Prosedur pembuatan pupuk organik cair dilakukan sebahgai berikut : Disiapkan polytank besar bertutup berkapasitas $150 \mathrm{~L}$ yang bersih. Bahan-bahan yang digunakan dihaluskan. Kemudian semua bahan dimasukkan ke dalam polytank dengan komposisi bahan cair $70 \%$ dan padat $30 \%$. Lakukan pengadukan selama 15 menit lalu tutup rapat (karena proses ini menggunakan bacteri anaerob). Tiap 3 hari sekali harus dibuka dan diaduk selama 15 menit. Setelah 1 bulan pupuk organik cair siap digunakan (tanda-tanda jadi yaitu bau tidak menyengat dan warna cairan dan bahan hitam kecoklatan). Pupuk organik cair yang dibuat kemudian dianalisis untuk mengetahui kadar C organik, Nitrogen total, Kalium dan Phospor. Untuk aplikasi pada tanaman pupuk organik cair yang dihasilkan disaring, lalu semprotkan ketanaman dengan konsentrasi 1 gelas 200 ml/tangki semprot. Ampasnya bisa dikeringkan dan digunakan sebagai pupuk organik padat. 


\section{HASIL DAN PEMBAHASAN}

Pelaksanaan kegiatan sosialisasi dilakukan di Aula Kantor Kepala Desa Sukadamai Timur, yang dihadiri oleh Kepala Desa Sukadamai Timur, Ketua Kelompok tani Maju II, perwakilan ketua kelompok tani Sidodadi beserta kader dari kedua kelompok tani dan beberapa masyarakat Sukadamai Timur. Dalam kegiatan ini Tim pelaksana telah mensosialisasikan tujuan kegiatan IbM, target dan luaran yang akan dicapai, dan juga telah menjelaskan pemanfaatan limbah ternak sapi yang dapat diolah dengan teknik sederhana menjadi pupuk organik cair. Dijelaskan juga beberapa keuntungan dan kemudahan dalam pemanfaatan/penggunaan pupuk organik.

Hasil yang dicapai pada tahap kegiatan ini adalah masyarakat khususnya anggota kader dari kedua mitra telah memiliki pengetahuan dan wawasan tentang
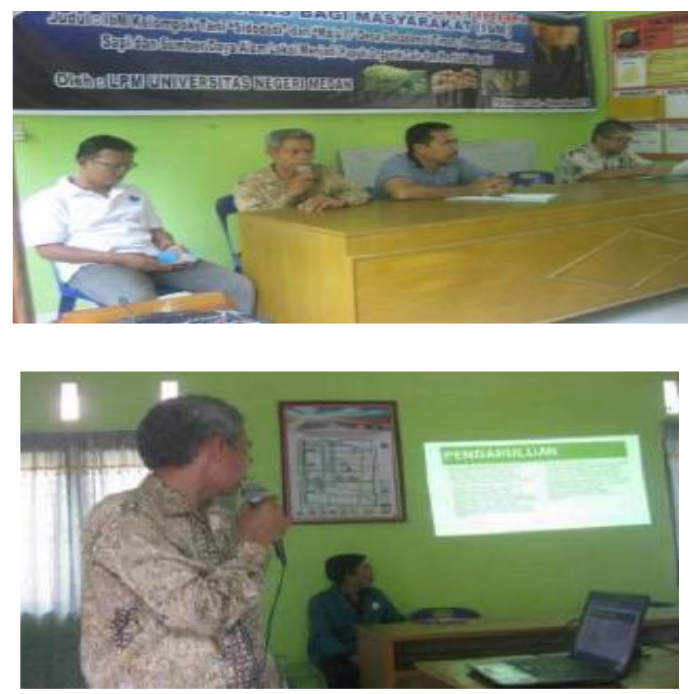

pemanfaatan limbah ternak sapi menjadi pupuk organik cair. Pelaksanaan pelatihan pembuatan pupuk organik cair telah dilaksanakan oleh tim pelaksana dengan anggota kader dari kedua mitra. Pelaksanaaan kegiatan dilakukan di peternakan milik anggota kelompok tani Maju II. Sebelum pelaksanaan pelatihan, tim pelaksana bersama dengan kedua mitra melakukan proses persiapan alat dan bahan-bahan yang dibutuhkan. Proses pelaksanaan pelatihan dilakukan dalam bentuk praktek pembuatan pupuk organik cair dari limbah ternak sapi yang terdiri dari feses dan urin dan dari bahan-bahan yang lain yang mudah diperoleh didampingi oleh mahasiswa dan tim pelaksana. Dokumentasi sosialisasi, penyuluhan dan pelatihan terlihat pada gambar 1 dan 2 berikut :
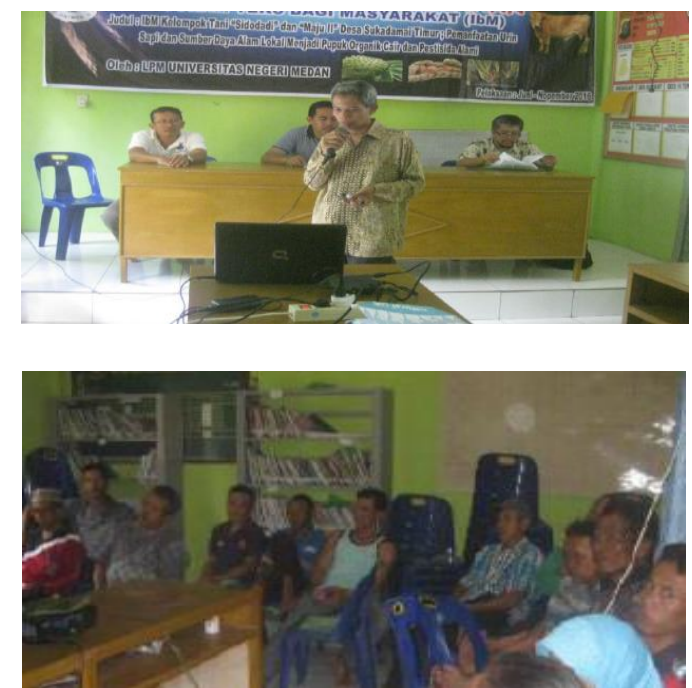

Gambar 1. Kegiatan sosialisasi IbM dan penyuluhan pembuatan pupuk organik cair
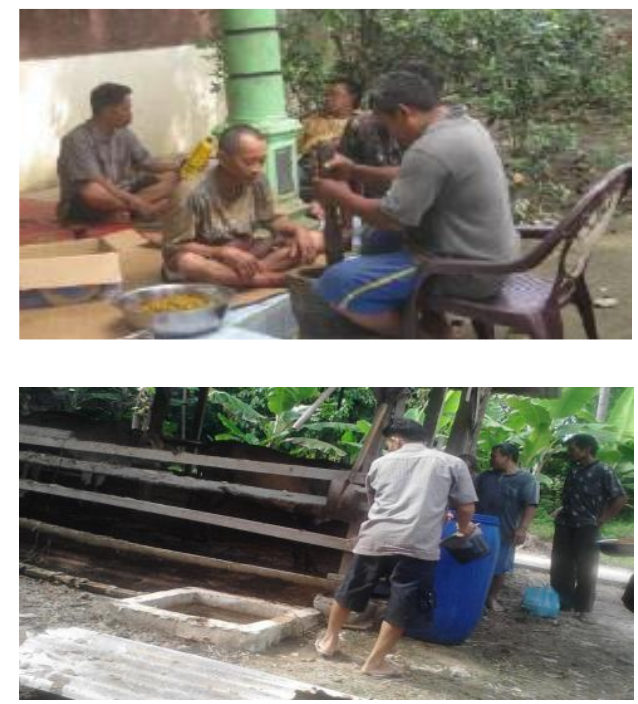
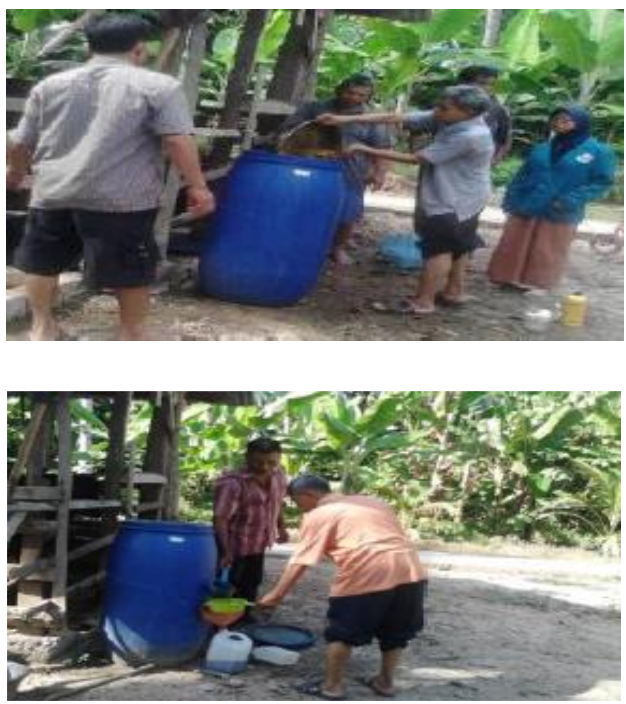

Gambar 2. Pelatihan pembuatan pupuk organik cair 
Pada kegiatan ini terlihat peran serta anggota kader dari kedua mitra tergolong aktif, dapat dilihat dari keseriusan dan peran serta setiap anggota mitra dalam mengikuti sosialisasi dan penyuluhan serta pelatihan pembuatan pupuk organik cair. Peran serta anggota mitra terlihat dari pembagian tugas kepada masingmasing anggota kader mitra untuk mengontrol proses fermentasi pupuk organik cair hingga terjadinya pupuk organik cair yang dibuat, setelah itu anggota
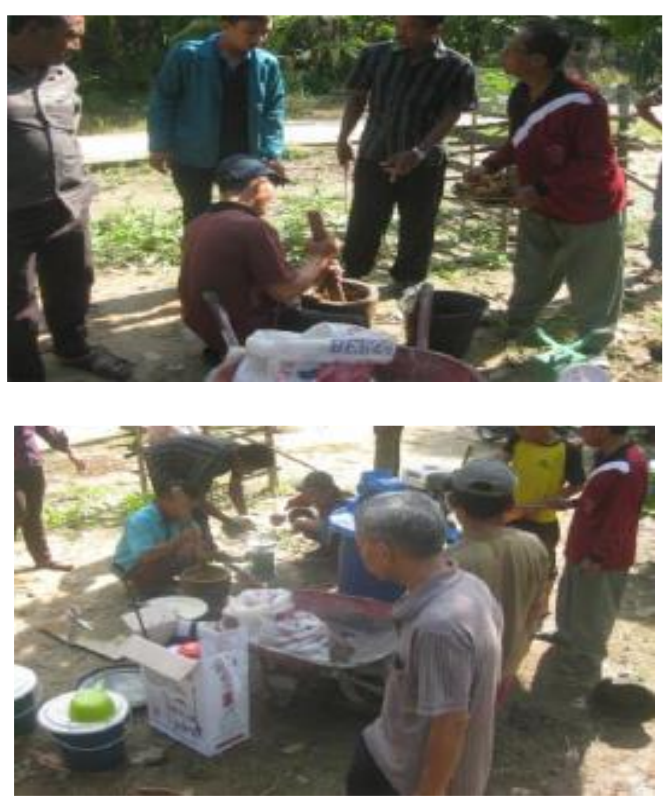

kader dari kedua mitra bersama tim pelaksana mengambil sampel pupuk organik cair yang dihasilkan untuk dilakukan uji terhadap kandungan hara makro. Tahap selanjutnya adalah melakukan pendampingan kepada masing-masing mitra dalam pembuatan pupuk organik cair secara mandiri dari limbah ternak sapi dengan metode fermentasi. Dokumentasi kegiatan terlihat pada gambar 3 .
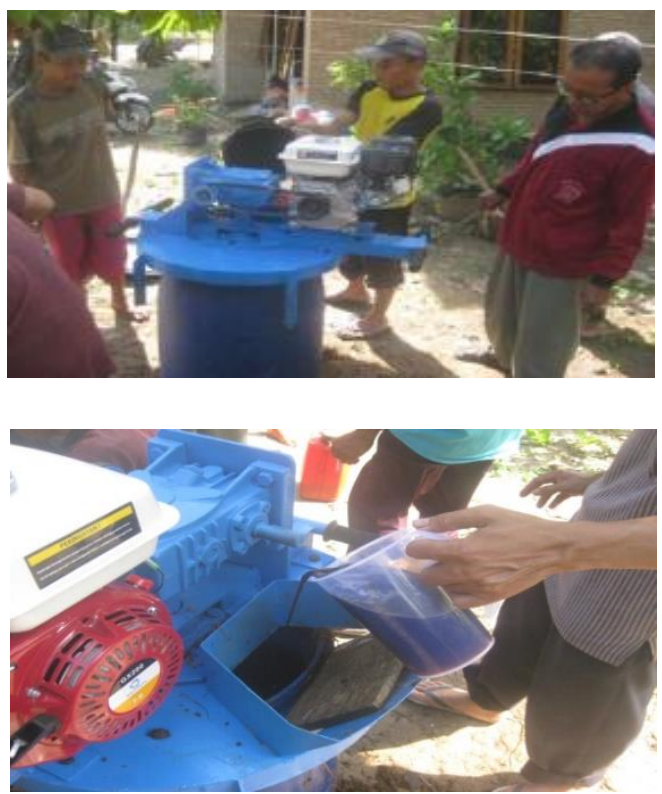

Gambar 3. Pendampingan pembuatan pupuk organik cair

Pada kegiatan pendampingan kedua mitra menunjukkan antusias dan keseriusan dilihat dari kehadiran anggota kader dari kedua mitra yang telah meluangkan waktu dan tenaga secara sukarela, mereka dengan sungguh-sungguh menyiapkan bahan baku dalam pembuatan pupuk organik cair. Begitu juga pada saat proses pembuatan pupuk organik cair. Selain itu kegiatan ini juga didukung oleh Kepala Desa Sukadamai Timur yaitu Bapak Riyadi, mulai dari proses perizinan, penyediaan tempat Aula kantor Kepala Desa pada saat pelaksanaan sosialisasi dan penyuluhan demikian pula dukungan pada saat pelatihan dan pendampingan kegiatan. Antusias yang besar dari kedua mitra juga dapat dilihat dari beberapa masukan dan perbaikan yang dilakukan untuk pelaksanaan teknis dilapangan, dengan tujuan untuk mensukseskan kegiatan program ini.

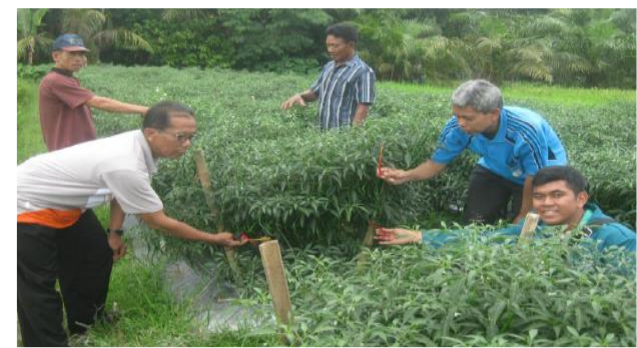

Analisis terhadap pupuk cair yang dihasilkan diperoleh kadar $\mathrm{C}$ organik : 1,22 \%, $\mathrm{N}$ total : $0,10 \%$, P $0,09 \%$ dan K $0,10 \%$, meskipun kadar NPK dari pupuk organik cair yang dibuat belum memberi pengaruh yang positif terhadap tanaman.

Aplikasi pupuk organik cair yang dilakukan terhadap tanaman cabe menunjukkan hasil yang menggembirakan dimana pertumbuhan cabe tumbuh subur dengan daun yang bagus dan berbuah sangat banyak, hal ini menunjukkan pupuk organik cair yang dibuat sudah berfungsi dengan baik. Dengan demikian biaya untuk pemupukan dapat ditekan sehingga berdampak pada kesejahteraan anggota kelompok tani. Dokumentasi aplikasi pupuk cair pada tanaman cabe terlihat pada gambar 4 berikut.

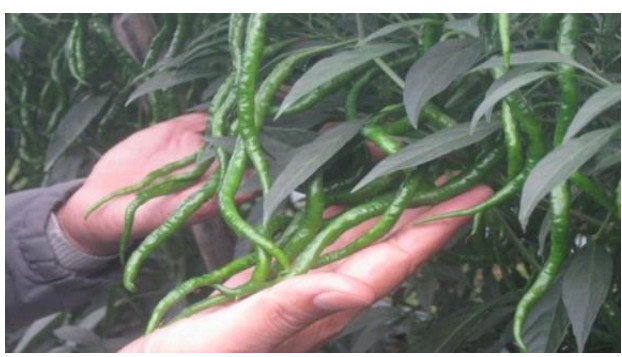

Gambar 4. Aplikasi pupuk cair pada tanaman cabe 


\section{KESIMPULAN}

Kegiatan pemanfaatan urin sapi pupuk organik cair kelompok tani desa Sukadamai Timur telah dilaksanakan, beberapa kesimpulan yang dapat diambil adalah :

a) Anggota kader dari kedua mitra yaitu Kelompok Tani "Sidodadi" dan "Maju II" desa Sukadamai Timur telah memiliki pengetahuan tentang pemanfaatan limbah ternak sapi menjadi pupuk organik cair.

b) Anggota kader dari kedua mitra telah memiliki keterampilan dalam proses pembuatan pupuk organik cair.

c) Produk pupuk organik cair yang dibuat memiliki kadar C organik : $1,22 \%, \mathrm{~N}$ total : 0,10\%, P : 0,09 $\%$ dan K $0,10 \%$.

d) Pupuk organik cair berpengaruh positif terhadap tanaman, sehingga dapat membantu meningkatkan pendapatan dan kesejahteraan petani/peternak.

\section{UCAPAN TERIMA KASIH}

Ucapan terimakasih disampaikan kepada DRPM Kemristek Dikti dan LPM Universitas Negeri Medan serta Kepala Desa Sukadamai Timur yang telah membiayai dan membantu sehingga kegiatan Pengabdian Kepada Masyarakat ini dapat terlaksana.

\section{DAFTAR PUSTAKA}

Amilla, Y. (2011). Penggunaan Pupuk Organik Cair Untuk Mengurangi Dosis Penggunaan Pupuk Anorganik pada Padi Sawah (Oryza Saliva L.), Laporan Penelitian, Departemen Agronomi dan Holtikultura, Fak. Pertanian, IPB, Bogor.

Anonim. (2008), Membuat Pupuk Cair Bermutu dari Limbah Kambing, warta penelitian dan pengembangan pertanian, Vol. 30 No. 6 , http://pustaka.litbang.pertanian.go.id/publikasi /wr306083.pdf, diakses 16 Pebruari 2015.

Lingga., P. (1991). Nutrisi Organik dari Hasil Fermentasi. Yogyakarta: Pupuk Buatan Mengandung Nutrisi Tinggi.

Saputra, Y.E. (2007). Pupuk Kompos, Keniscayaan bagi Tanaman, http://www.chem-istry.org/artikel kimia/pupuk kompos keniscay aan_bagi_tanaman/ Diakses 12 April 2014.

Simamora, S. dan Salundik. (2008). Meningkatkan Kualitas Kompos. Jakarta : AgroMedia Pustaka.

Sudiarto, B. (2008). Pengelolaan Limbah Peternakan Terpadu dan Agribisnis yang Berwawasan Lingkungan, Seminar Nasional Teknologi Peternakan dan Veteriner, Bandung. 52-60.

Widjayanto, D.W., and Miyauchi, N. (2003). Organic Farming and its Prospect in Indonesia. Bull. Fac. Agric. Kagoshima Univ. 52: 57-62. 